\title{
Liquid of Organic Fertilizer from Waste of Market Convensional System Applied on Agronomic Observation of Setaria Splendida Stapf at Various Ages Defoliation
}

\author{
Eko Hendarto ${ }^{1, *}$ and Muslihudin Muslihudin ${ }^{2}$ \\ ${ }^{1}$ Faculty of Animal Husbandry, Jenderal Soedirman University, Purwokerto - Indonesia \\ ${ }^{2}$ Faculty of Social and Political Science, Jenderal Soedirman University, Purwokerto - Indonesia
}

\begin{abstract}
Market conventional system given organic waste can be used for liquid of organic fertilizer. The research of liquid of organic fertilizer was carried out on Setaria Splendida Stapf that defoliated at different ages. The design used is a Completely Randomized Design. The treatments given are 3 (three) mixtures of liquid of organic fertilizer with water, namely 1:1, 1:2 and 1:3 (liquid of organic fertilizer: water) and defoliation age, 35, 40 and 45 days. Each combination treatment was repeated 3 times on a $1 \times 2$ meter plot. The agronomic parameters observed were plant height, number of tillers, number of leaves, area of canopy and weed growth. The results of the study were analyzed by means of a Completely Randomized Design, continued with a regression test. The results of the analysis show that the older defoliation age shows the agronomic aspects of Setaria Splendida Stapf grass which are getting better while the doses of liquid of organic fertilizer are getting runny, the growth rate decreases. The best agronomic level obtained at the age of defoliation is getting older ( 45 days) with fertilization from liquid of organic fertilizer resulting from more concentrated waste of market conventional system (1:1).
\end{abstract}

Keywords: Liquid of organic fertilizer; Setaria Splendida Stapf; plant agronomy.

\section{Introduction}

One of the negative impacts of market conventional systems is the abundance of organic waste and pollution of the environment. Waste organic of market conventional system can be processed into liquid of organic fertilizer. The fertilizer was be used in the cultivation of feed crops. The use of liquid of organic fertilizers is not yet popular in the community while the use of waste organic from market conventional system is encouraged to be widely used. The advantages of liquid of organic fertilizer in fertilizing activities are easy to use and the nutrients needed are easily absorbed by plants. Setaria Splendida Stapf is one of the feed plants that is favored by livestock so that its utilization is more applicable [1]. Forage needs of ruminants in large quantities, obtained from leaves and other plant parts that have good quality [2].

Liquid fertilizer as an organic element, its chemical content is low, its nutrients are good for fulfilling the needs of plants, if there is an excess in the soil, prosses absorption of plants can easily [3]. This capability, according to [4], there is also liquid fertilizer produced by market conventional system organic waste, even related to the potential that exists, will provide good prospects for various dynamics of human life, including reducing environmental pollution and extending the life of landfill (Place Waste Final Processing). The less garbage from the results of the dynamics of human life dumped into the landfill, the longer the age of the landfill. According to [5], the amount of organic waste from a market conventional system can reach up to 8 trucks per day, an amount that can disrupt human life, but at the same time supports human life through the management of technology into liquid of organic fertilizer.

Applicatively, basically liquid of organic fertilizer can be used for various plants including feed plants. The age of the feed plant is determined based on the needs of livestock. Young and old plants determine the carrying capacity of livestock. The parameters of carrying capacity can be seen from the agronomy which, according to [6] includes the height and number of plants, number of leaves, canopy area and growth ability that can be observed from the number of weeds that grow in plant growth plots. In this regard, a study was conducted on the application of liquid of organic fertilizer from market conventional system organic waste processing in the agronomic aspects of Setaria Splendida Stapf grass at various plant ages in an effort to support the ruminant livestock industry.

\section{Materials and Research Methods}

Experimental research has been carried out with the material of liquid of organic fertilizer produced by market conventional system organic wastes at various ages of the Setaria Splendida Stapf. Factorial experiments were

*Corresponding author: ekohendarto17@gmail.com 
carried out with a completely randomized design with 2 (two) factors, namely the age of defoliation (35, 40 and 45 days) and the mixture of liquid of organic fertilizer with water $(1: 1,1: 2$ and 1:3). The treatment combination was repeated 3 (three) times on a $1 \times 2$ meter plot so that there were 27 treatment combinations. The mixture of liquid of organic fertilizer from the processing of market conventional system organic wastes with water as in Table 1. Test the laboratory analysis of the quality of liquid of organic fertilizer produced by market conventional system waste is shown in Table 2.

Table 1. Use of mixed doses of liquid organic and water fertilizers

\begin{tabular}{|c|c|c|c|c|c|}
\hline $\begin{array}{c}\text { Numb } \\
\text { er }\end{array}$ & $\begin{array}{c}\text { Treat } \\
\text { ment } \\
\text { code }\end{array}$ & $\begin{array}{c}\text { Liquid } \\
\text { Waste } \\
\text { Organic } \\
\text { Fertilizer } \\
\text { Market }\end{array}$ & $\begin{array}{c}\text { Water } \\
\text { mixtur } \\
\mathrm{e}\end{array}$ & $\begin{array}{c}\text { Amou } \\
\text { nt of } \\
\text { liquid } \\
\text { fertiliz } \\
\text { er }\end{array}$ & $\begin{array}{c}\text { Usage } \\
\text { area }\end{array}$ \\
\hline 1 & $\begin{array}{c}\mathrm{C}-1 \\
(1: 1)\end{array}$ & 0,30 liter & $\begin{array}{c}0,30 \\
\text { liter }\end{array}$ & $\begin{array}{c}\mathrm{O}, 6 \\
\text { liter }\end{array}$ & $2 \mathrm{~m}^{2}$ \\
\hline 2 & $\begin{array}{c}\mathrm{C}-2 \\
(1: 2)\end{array}$ & 0,20 liter & $\begin{array}{c}0,40 \\
\text { liter }\end{array}$ & $\begin{array}{c}0,6 \\
\text { liter }\end{array}$ & $2 \mathrm{~m}^{2}$ \\
\hline 3 & $\begin{array}{c}\mathrm{C}-3 \\
(1: 3)\end{array}$ & 0,15 liter & $\begin{array}{c}0,45 \\
\text { liter }\end{array}$ & $\begin{array}{c}0,6 \\
\text { liter }\end{array}$ & $2 \mathrm{~m}^{2}$ \\
\hline
\end{tabular}

Table 2. Laboratory test results of liquid of organic fertilizer from waste of market conventional system

\begin{tabular}{|c|c|c|c|}
\hline Number & Composition & Notation & Total \\
\hline 1 & Organic Carbon & $\%$ & 0,035 \\
\hline 2 & Total Nitrogen & $\%$ & 0,038 \\
\hline 3 & Combined ingredients & $\%$ & 0 \\
\hline 4 & $\mathrm{C} /$ N ratio & $\%$ & 0,920 \\
\hline 5 & Organic ingredients & $\%$ & 0,060 \\
\hline 6 & $\mathrm{pH}$ & & 8,070 \\
\hline 7 & $\mathrm{P}_{2}$ O5 total & $\mathrm{mg} / 1$ & 81,748 \\
\hline 8 & $\mathrm{~K}_{2}$ O total & $\%$ & 0,134 \\
\hline 9 & Fe total & $\mathrm{mg} / 1$ & 5,896 \\
\hline 10 & Mn total & $\mathrm{mg} / 1$ & 4,930 \\
\hline 11 & Cu total & $\%$ & 0 \\
\hline 12 & Zn total & $\mathrm{mg} / 1$ & 1,548 \\
\hline 13 & B total & $\mathrm{mg} / 1$ & 2,621 \\
\hline 14 & Co total & $\mathrm{mg} / 1$ & 1,239 \\
\hline
\end{tabular}

Soil Laboratory, Faculty of Agriculture, Unsoed (2018)

The agronomic variables studied were height, number of plants, number of leaves and width of the canopy and the number of weeds. The working procedure is after the soil is processed, the Setaria Splendida Stapf plant is planted. At 2 weeks old plants are forcibly defoliationed for uniform growth. Two weeks later fertilized according to the prescribed dose. At the age of 35 days, agronomic observations were carried out and 9 plots were defoliationed, at 40 days agronomic observations were carried out and 9 plots were defoliation and 45 days of age were carried out with agronomic observations and 9 plots were defoliationed. Data obtained were analyzed based on Complete Random Design. The effect of treatment is carried out regression test.

\section{Results and Discussion}

\subsection{Research Location Conditions}

The study was carried out in an open yard. The results of analysis of soil quality from the research land showed that the nitrogen content was 48.15 ppm (very high), $\mathrm{P}_{2} \mathrm{O}_{5}$ was available $0.28 \mathrm{ppm}$ (very low) and $\mathrm{K}_{2} \mathrm{O}$ was available at 0.49 percent (medium). The class of clay texture with sand fraction was $23.36 \%$, dust fraction $19.5 \%$ and clay $57.14 \%$, soil acidity degree 6.01 .

The research land has a normal acidity level, soil structure and nitrogen content showing soil conditions according to [7] both for crop cultivation and supporting agronomic grass growth. Setaria Splendida Stapf according to [8] able to grow in broad conditions so that it is expected to be able to provide more beneficial information in research studies especially in relation to agronomy and strategies for applying liquid of organic fertilizer. regarding the results of the quality test of liquid of organic fertilizer, it shows that the nutrient content is low, this is in accordance with [9] study that the nutrients of liquid of organic fertilizer are generally not high, so the gift must be considered.

\subsection{Effect of Defoliation Age and Dosage of Liquid of Organic Fertilizer on the Height Plant of Setaria Splendida Stapf}

Natural resources in the form of market conventional system organic waste which is processed into liquid of organic fertilizer applied to Setaria Splendida Stapf cultivation, the results are listed in Table 3. Agronomic aspects in the form of grass plants are aspects that can be used to determine the quality of plant growth. The measurement results showed that the average size of the Setaria Splendida Stapf plant height was $42.76 \mathrm{~cm}$, in the range of $31.33 \mathrm{~cm}-52.15 \mathrm{~cm}$. These results are lower than the results of [10] which showed that the size of the Setaria Splendida Stapf plant height was $50.17 \mathrm{~cm}$, but at almost the same range.

Table 3 shows that the older the plants, the higher their height [11], the highest increase in size between the age of 40 days to 45 days which is as much as $5.22 \mathrm{~cm}$ while between 35 - 40 days, the addition is only $1.96 \mathrm{~cm}$. This is due to the high activity of photosynthesis that produces a lot of energy, one of which is used for the addition of plant height [12].

Table 3. Effect of defoliation age and dosage of liquid of organic fertilizer from organic waste of market conventional system at average height of Setaria Splendida Stapf (cm)

\begin{tabular}{|c|c|c|c|c|}
\hline \multirow{2}{*}{$\begin{array}{c}\text { Defoliat } \\
\text { ion Age }\end{array}$} & \multicolumn{2}{|c|}{ Liquid Organic Fertilizer + Water } & \multirow{2}{*}{ Average } \\
\cline { 2 - 4 } 35 days & $4: 1$ & $1: 2$ & $1: 3$ & \\
\hline 40 days & 43,67 & 40,67 & 36,67 & 39,67 \\
\hline 45 days & 49,00 & 41,67 & 39,67 & 41,67 \\
\hline Average & 44,78 & 43,33 & 42,33 & 46,89 \\
\hline
\end{tabular}

Source: processed from primary data (2018) 


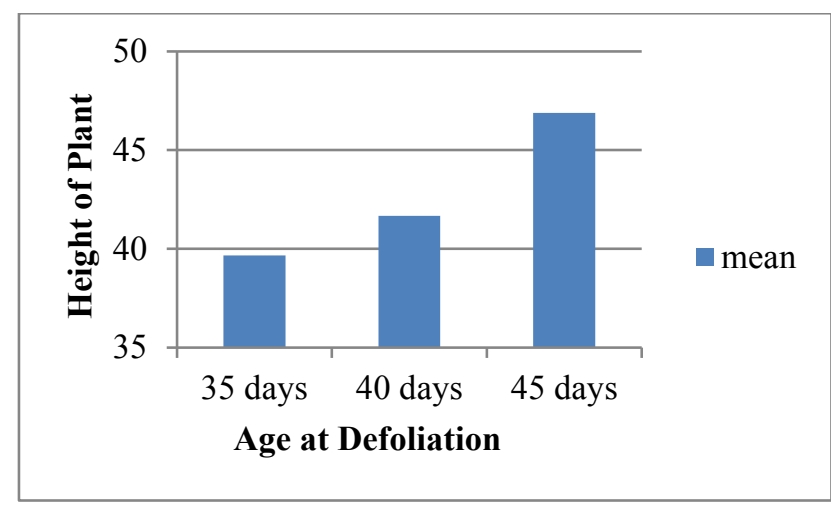

Fig. 1. The mean of height of Setaria Splendida Stapf under the effects of age at defoliation

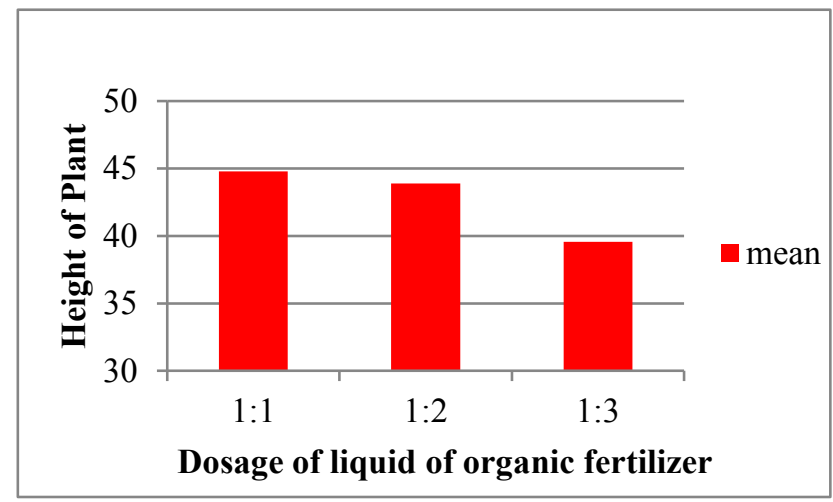

Fig. 2. The mean of height of Setaria Splendida Stapf under effects of the dosage of liquid of organic fertilizer from waste of market conventional system

Table 3 also shows that the more dilute the liquid of organic fertilizer given, the lower the size of the plant height. the nutrient content of liquid of organic fertilizer will be lower in the more water given [13] so that the response to plants is also lower [14]. The application of liquid fertilizer in an effort to utilize market Conventional system organic waste, the day's content is ready to be absorbed by the roots of plants, the response is possible after the plants are more than 40 days old. At each dilution dose, it has responded to the plant age of 40 days for plant height parameters.

In more runny doses, there is a decrease in plant size. [15], that land with lower nitrogen content has an adverse effect on growth, including plant height. At the age of older defoliations with more dense fertilizer dosage, the highest plant height $(44.78 \mathrm{~cm})$ was measured. This is in accordance with [14] and [16] that the longer the plant's age the more visible its growth.

The treatment given did not affect $(\mathrm{P}>0.05)$ on plant size, but defoliation age had an affect $(\mathrm{P}<0.05)$ while the dose of liquid of organic fertilizer had no effect $(p>0.05)$. this shows that there are significant differences in the size of plant height in the treatment of defoliation age, but uniform in the treatment of liquid of organic fertilizer doses. it is suspected that low nutrient content, especially nitrogen, from liquid of organic fertilizer has not been able to give agronomic significance to plants, especially parameters of plant height.

As a potential natural resource in human life, it is possible to need another strategy in the utilization of liquid of organic fertilizer from market conventional system waste in its application for feed crops [10]. These strategies include fertilization time, fertilizer dosage, fertilization technique, mixture with other materials and so on.

Based on the treatment given, it shows that the older the plant and the more concentrated or the less water mixture given to the liquid fertilizer produced by market conventional system organic waste, the higher the size of the plant height.

\subsection{Effect of Defoliation Age and Liquid of Organic Fertilizer Dosage on the Number Tillers of Setaria splendida Stapt}

The number of plants in the grass will affect the level of production. The more plants, the higher the level of production [17]. In Table 4 shows older age, number of plants, it is possible the production of forage is higher and the more the mixture of water in liquid of organic fertilizer the fewer the number of plants. this is in accordance with [18] that the number of plants in grass cultivation plays an important role in terms of production functions.

The average number of Setaria Splendida Stapf plants per clump is 22.67 stems (Table 4) in the range of 15-29 plants per clump. Table 4 shows that the age of thicker plants increases the number of plants [19], while in the lesser mixture of water, the liquid of organic fertilizer given is increasingly concentrated so that the concentration of the nutrient elements increases and results in an increase in the number of plants [20]. This is in accordance with the opinion of [21] that nutrients contained in fertilizers also determine aspects of plant growth. [3] study also showed that the lower doses of liquid fertilizers from livestock caused the plant response to decline in carrot plants.

The treatment did not affect $(\mathrm{P}>0.05)$ on the number of Setaria Splendida Stapf plants, but defoliation age had an affect $(\mathrm{P}<0.05)$ while the dose of liquid of organic fertilizer had no affect $(\mathrm{P}>0,05)$. This shows that the treatment of defoliation age gives a difference in the number of plants, but uniformly in the treatment of doses of liquid of organic fertilizer. plants at the age of 35 days to 40 days have increased the number of plants by 2.04 plants while from the age of 40 to 45 only add 1.45 plants. It is suspected that the nutrient content of the fertilizer is low so the intensity of the addition is not so significant, while in general, the Setaria Splendida Stapf plants are fast in increasing the number of plants $[22,23]$. [24] added that the reduction in nutrient levels due to dilution resulted in a decrease in plant growth also the number of plants per clump. Defoliationing time of 45 days with a dose of liquid of organic fertilizer with a mixture of water 1: 1 gives the highest number of Setaria Splendida Stapf plants $(23,56$ plants). 
Table 4. Effects of defoliation age and dosage of liquid of organic fertilizer from organic waste organic of market conventional system at average number tillers of Setaria Splendida Stapf (stems)

\begin{tabular}{|c|c|c|c|c|}
\hline \multirow{2}{*}{$\begin{array}{c}\text { Defoliat } \\
\text { ion Age }\end{array}$} & \multicolumn{2}{|c|}{ Liquid of organic fertilizer + Water } & \multirow{2}{*}{ Average } \\
\cline { 2 - 4 } 35 days & $21: 1$ & $1: 2$ & $1: 3$ & \\
\hline 40 days & 24,33 & 20,67 & 19,33 & 20,56 \\
\hline 45 days & 24,67 & 23,67 & 21,00 & 23,00 \\
\hline Average & 23,56 & 23,11 & 23,67 & 24,45 \\
\hline
\end{tabular}

Source: processed from primary data (2018)

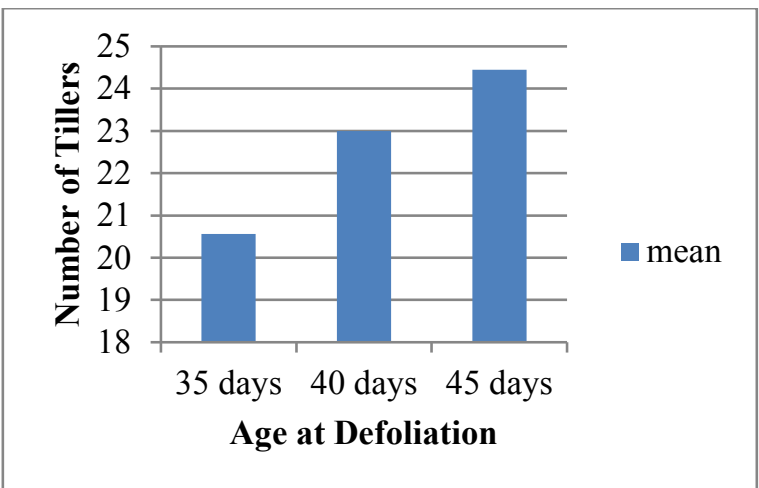

Fig. 3. The mean of the number of tillers of Setaria Splendida Stapf under the effects of age at defoliation

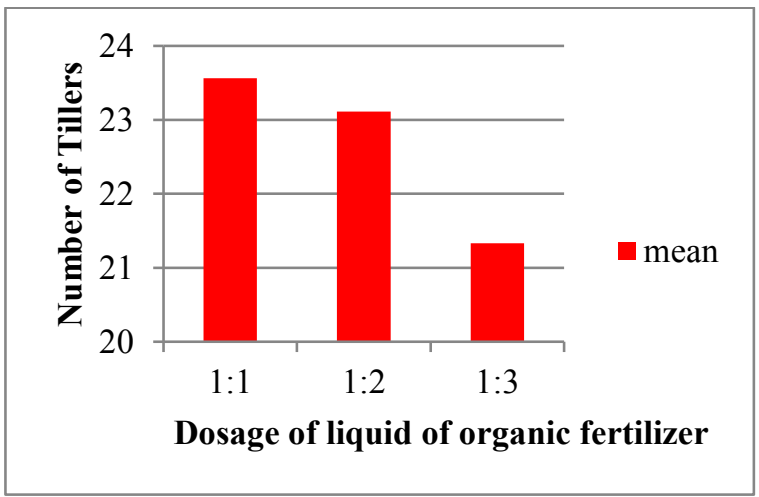

Fig. 4. The mean of the number of tillers of Setaria Splendida Stapf under effects of the dosage of liquid of organic fertilizer from waste of market conventional system

\subsection{Effect of Defoliation Age and Liquid of Organic Fertilizer Dose on Setaria Splendida Stapf Leaves}

The appearance of leaf number parameters is one of the considerations for the production of feed plants. Table 5 shows the average number of leaves per Setaria Splendida Stapf cluster of 165.63 leaves. The quality of forage plants is strongly influenced by leaf conditions [25]. Each addition of leaves will add to the fresh weight of [26]. Hendarto [27] stated that breeders would prefer leaves in large quantities and preferred by livestock, further improving livestock performance.
Table 5. Effect of defoliation age and dosage of liquid of organic fertilizer from organic waste of market conventional system at average number of leaves of Setaria Splendida Stapf (leaf blade)

\begin{tabular}{|c|c|c|c|c|}
\hline \multirow{2}{*}{$\begin{array}{c}\text { Defoliation } \\
\text { Age }\end{array}$} & \multicolumn{3}{|c|}{ Liquid of organic fertilizer +} & \multirow{2}{*}{ Average } \\
\cline { 2 - 4 } & $1: 1$ & $1: 2$ & $1: 3$ & \\
\hline 35 days & 139,67 & 136,33 & 119,33 & 131,78 \\
\hline 40 days & 169,00 & 163,33 & 141,67 & 158,00 \\
\hline 45 days & 223,00 & 218,67 & 179,67 & 207,11 \\
\hline Average & 177,22 & 172,78 & 146,89 & 165,63 \\
\hline
\end{tabular}

Source: processed from primary data (2018)

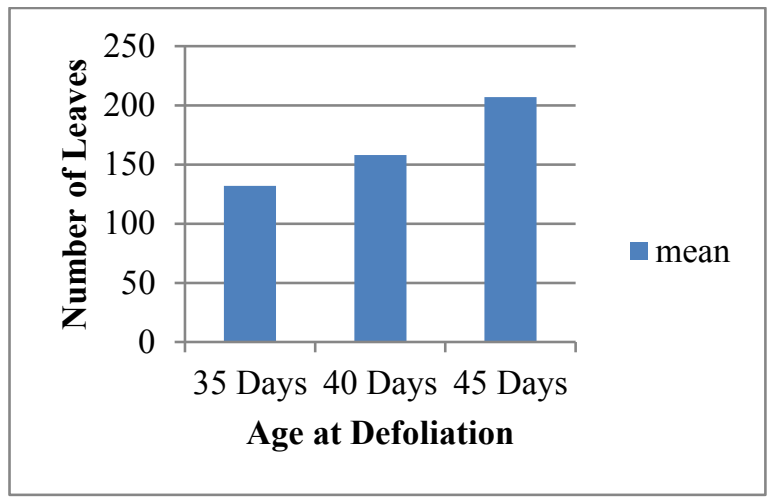

Fig. 5. The mean of the number of leaves of Setaria Splendida Stapf under the effects of age at defoliation

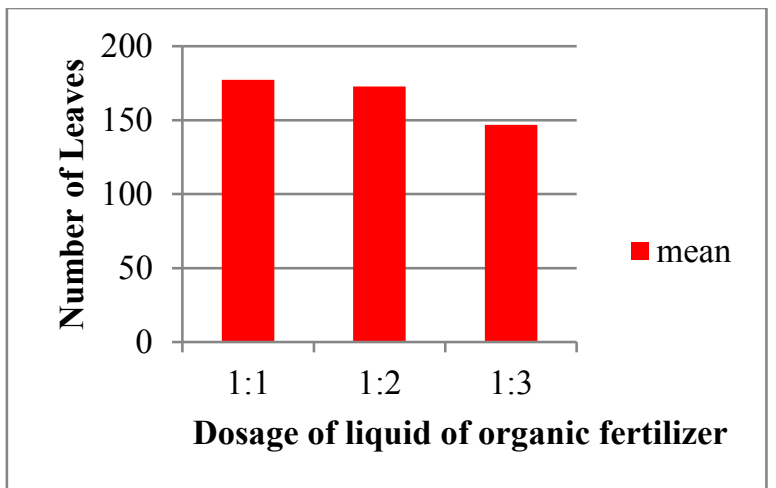

Fig. 6. The mean of the number of leaves of Setaria Splendida Stapf under effects of the dosage of liquid of organic fertilizer from waste of market convensional system

Plots defoliationed older, show more leaves, while in liquid of organic fertilizer, the average number of leaves is less runny. this is in accordance with research of [28] that in the study of liquid of organic fertilizer in indigofera plants showed a smaller number of leaves in small nutrient content. Added that leaves are important biomass in the production of forage, leaves are the highest quality vegetative part. [29] added that plants with a higher size have more leaves.

Grass defoliationed at 35 days, in 5 days the leaves numbered 16.22 leaves, while up to 45 days the leaves increased again by 49.11 leaves. In this regard, it can be observed that the Setaria Splendida Stapf grass plant experienced more intensive growth at the age of $40-45$ days. It is possible to get better performance so Setaria Splendida Stapf can be defoliationed at 45 days. This is 
according to the opinion of [30] that each plant has its own productive age.

The results of variance analysis showed that defoliation age had a significant effect $(\mathrm{P}<0.05)$, but the dose of the mixture of liquid of organic fertilizer had no effect $(\mathrm{p}>$ 0.05 ) on the number of leaves of the Setaria Splendida Stapf plant. the age treatment of the defoliation shows that the linear equation is very real, which indicates that the growing age of the number of leaves increases.

Observe other agronomic aspects, showing that every increase in defoliation age and the more concentrated mixture of liquid of organic fertilizer from the processing of market convensional system wastes given a mixture of water on Setaria Splendida Stapf plants provide better conditions. Added by [21] and [31] that liquid of organic fertilizer can be used for all types of plants. Liquid of organic fertilizer contains 13 types of macro and micronutrients that are absolutely needed by plants, at the right concentration and can improve plant growth, once including the number of leaves.

\subsection{Effect of Defoliation Age and Liquid of Organic Fertilizer Dosage on Setaria Splendida Stapf Canopy}

Table 6 shows that the average area of Setaria Splendida Stapf plant canopy given liquid of organic fertilizer as a result of market conventional system organic waste defoliationed from the age of 35 days to 45 days is $102.9999 \mathrm{~cm} 2$. the conditions in the field and the average yield show uniformity of plant growth that is strong and soars up and to the side making the surrounding land canopied. these conditions indicate that plants grow well, plants get sunlight to support growth. [32] provided support that regardless of the addition of nitrogen from fertilizing activities including liquid of organic fertilizer with low elemental content, it has resulted in the growth and formation of chloropyll for the formation of a good leaf canopy.

The use of liquid of organic fertilizer in plants given through the soil also has an effect, it is possible to use can fertilization techniques through leaves which, according to [33], will get better effectiveness on agronomic and growth aspects. In broader parameters, the wider canopy of plants will provide better application to the effects of weeds that grow underneath.

Table 6. Effect of defoliation age and dosage of liquid of organic fertilizer from organic waste of market conventional system at average Setaria Splendida Stapf canopy width $\left(\mathrm{cm}^{2}\right)$

\begin{tabular}{|c|c|c|c|c|}
\hline \multirow{2}{*}{$\begin{array}{c}\text { Defoliation } \\
\text { Age }\end{array}$} & \multicolumn{2}{|c|}{ Liquid Organic Fertilizer + Water } & \multirow{2}{*}{ Average } \\
\cline { 2 - 4 } & $1: 1$ & $1: 2$ & $1: 3$ & \\
\hline 35 days & 82,9804 & 96,4572 & 82,6631 & 90,7002 \\
\hline 40 days & 105,3278 & 92,4273 & 93,6862 & 97,1471 \\
\hline 45 days & 128,2048 & 114,2690 & 120,9836 & 121,1525 \\
\hline Average & 105,5043 & 101,0512 & 99,1109 & 102,9999 \\
\hline
\end{tabular}

Source: processed from primary data (2018)

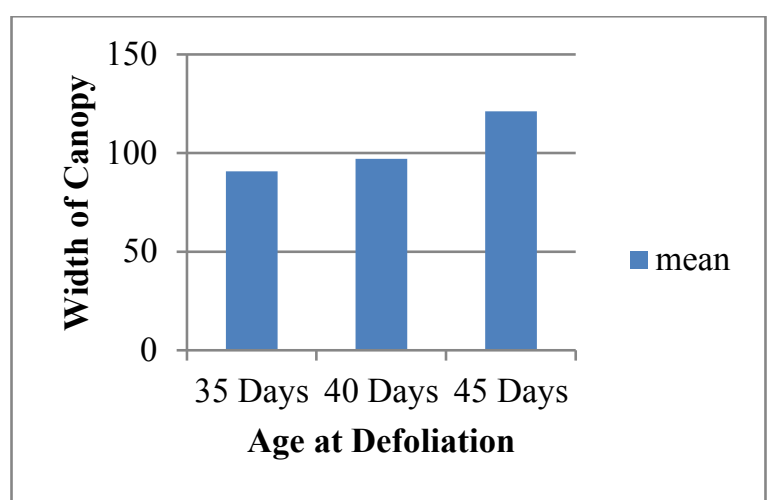

Fig. 7. The mean of canopy width of Setaria Splendida Stapf under the effects of age at defoliation

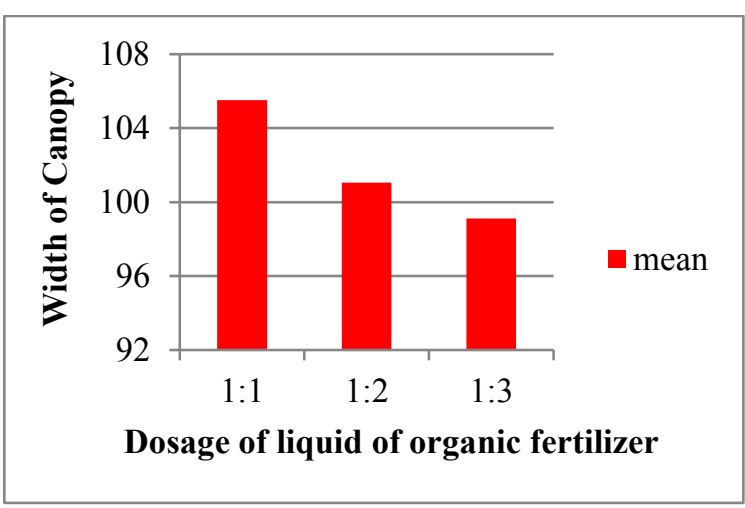

Fig. 8. The mean of canopy width of Setaria Splendida Stapf under the effects of the dosage of liquid of organic fertilizer from waste of market conventional system

ANOVA results showed that in the parameters of the Setaria Splendida Stapf canopy plant area, the treatment given had no effect $(\mathrm{P}>0.05)$. This shows that the results of the study are uniform so that the level of influence is also considered uniform in the broad aspects of the Setaria Splendida Stapf canopy. This is in accordance with the results of [6] that the use of liquid of organic fertilizer at various concentrations did not give different results on the parameters of potato growth. although there are differences between levels which show that the older the defoliation age, and the thicker the use of liquid of organic fertilizer, the plant canopy is wider, but it is considered uniform. Grass defoliationed at 45 days old with liquid of organic fertilizer mixed with a ratio of 1: 1 with water, showing the widest plant canopy.

\subsection{Effect of Defoliation Age and Liquid of Organic Fertilizer Dosage on the Value of Many Weeds of Setaria Splendida Stapf}

Nutrients that should be intended for the process of plant growth can be captured by weeds that do not want their existence, so it must be removed [34]. The level of weed growth will give an idea of the growth conditions of the feed plants [35]. The results indicated that the average level of the value of weeds in Setaria Splendida Stapf, showed a value of 2.26 , which meant that the growth of the weeds was not too developed or quite small in the range of 1 - 5 (very little). This condition is caused by Setaria Splendida Stapf that has a good canopy, which is wide enough to 
cover the chance of weeds getting sunlight so that weed growth is hampered [36]. Table 7 shows Setaria Splendida Stapf grass defoliationed at 45 days old with concentrated liquid of organic fertilizer, the smallest value of the best (best), but at the same age as the diluted liquid of organic fertilizer, the value of the weeds is the best (at least good). observing this, fertilizing with liquid of organic fertilizer has an influence on weed growth. it is possible for liquid of organic fertilizer to produce concentrated market conventional system organic waste, which is only given one part water mixture, more nutrient content, thus supporting the growth of Setaria Splendida Stapf and producing lush plant conditions with a broad canopy level and then weed growth becomes inhibited. The opposite condition in watery organic fertilizers produces more weeds.

If related to other agronomic aspects, namely the size of plant height, number of plants, number of leaves and canopy area of Setaria Splendida Stapf, it indicates the suitability of the condition with the growth value of weeds found under plant clumps. In high Setaria Splendida Stapf, the number of plants is large and the canopies are wide, the value of growth in weeds is low. This condition is related to the thickness of the doses of liquid of organic fertilizer mixture. At thick doses, the elemental content is more so that it has supported higher agronomic aspects and fewer weeds.

Table 7. Effects of defoliation age and dosage of liquid of organic fertilizer from organic waste of market conventional system on the average number of values of Setaria Splendida Stapf weed

\begin{tabular}{|c|c|c|c|c|}
\hline \multirow{2}{*}{$\begin{array}{c}\text { Defoliation } \\
\text { Age }\end{array}$} & \multicolumn{3}{|c|}{ liquid of organic fertilizer +} & \multirow{2}{*}{ Wverage } \\
\cline { 2 - 4 } & $1: 1$ & $1: 2$ & $1: 3$ & \\
\hline 35 days & 2,33 & 2,67 & 2,67 & 2,56 \\
\hline 40 days & 1,67 & 2,00 & 2,67 & 2,11 \\
\hline 45 days & 1,33 & 2,00 & 3,00 & 2,11 \\
\hline Average & 1,78 & 2,22 & 2,78 & 2,26 \\
\hline
\end{tabular}

Source: processed from primary data (2018)

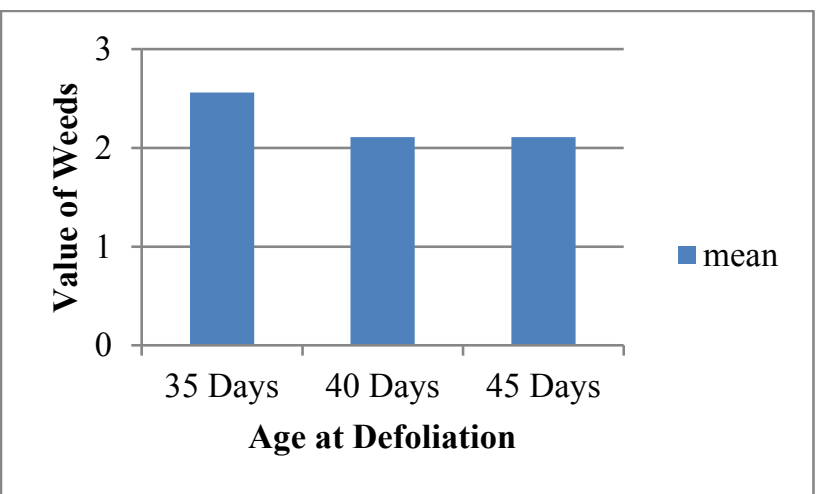

Fig. 9. The mean of the value number of weeds of Setaria Splendida Stapf under the effects of age at defoliation

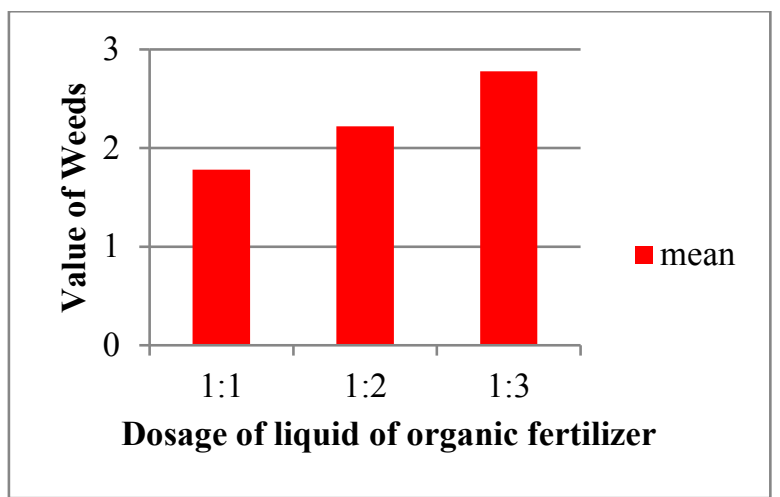

Fig. 10. The mean of the value number of weeds of Setaria Splendida Stapf under effects of the dosage liquid of organic fertilizer from waste of market convensional system

The results of the variance analysis showed that the treatment of plant age and dosage of liquid of organic fertilizer had no significant effect $(\mathrm{P}>0.05)$ on the value of Setaria Splendida Stapf weed growth. The agronomic aspect of Setaria Splendida Stapf growth causes weed growth to be relatively inhibited so that even though there are differences it is considered uniform. Adaptation ability in Setaria Splendida Stapf clumps can suppress weed growth [8].

\section{Conclusion}

The conclusions that can be obtained from the research and discussion about of liquid of organic fertilizer from organic waste of market conventional system in the agronomy of Setaria Splendida Stapf plants defoliation at different ages is that on grass defoliationed older up to 45 days and dosage more concentrated liquid of organic fertilizer (one part liquid of organic fertilizer and one part water) shows there is an increase in conditions in its agronomic aspects. in order to make better use of human life from natural resources in the form of market conventional system organic waste, the waste can be processed in the form of liquid of organic fertilizer and can be used as fertilizer for plants to reduce the level of environmental pollution.

\section{References}

1. S. Aminudin, E. Hendarto, Textbook on Agrostology (Faculty of Animal Husbandry Jenderal Soedirman University, Purwokerto, 2000)

2. E. Hendarto, J. Rur Dev, 5 (2), 77-85 (2005)

3. R. Taufika, J. Horti. P, 8 (2), 1-10 (2011)

4. E. Hendarto, Muslihudin, N.L. Rahayu, Y. A. Romadhon, Influence of Liquid of Organic Fertilizer On The Production and Quantifying Capacity of Livestock From Setaria splendida Stapt (Setaria splendida stapf) (International Conference on Energy, Environment and Information System (ICENIS) Proceedings, School of Postgraduate Studies Diponegoro University, Semarang, 2018)

5. E. Hendarto, E. Widyastuti, D.R. Puspita, A. Iqbal, E. Hilmi, Muslihudin, E. Dewanto, S. Anwar, E.B. Riyanto, S.A. Amir, Analysis of Environmental 
Problems in Regions and Developable Solutions (Center for Environmental Research, Institute for Research and Community Service, Jenderal Sudirman University, Purwokerto, 2011)

6. S. Parman, An. Phys. Bull, 15 (2), 21-31 (2007)

7. J.F.S. Ferreira, M.V. Cornacchione, X. Liu, D.L. Suarez, J. Agr, 5, 577-597 (2015)

8. M.M. Rahman, M. Tateyama, M. Niimi, R.B Abdullah, W.E Wan Khadijah, O. Kawamura, Pakistan J. of Bio Sc (2013)

9. A. Wachjar, L. Kadarisman, Agr. Bull, 35 (3), 212-16 (2007)

10. E. Hendarto, Suwarno, The Application of Liquid Fertilizer made from Market Convensional system Organic Wastes on Growth of Setaria splendida Stapt (Setaria splendida stapf), (International Conference on Energy, Environment and Information System (ICENIS) Proceedings, School of Postgraduate Studies Diponegoro University, Semarang, 2017)

11. C.C. Onyeonagu, Ugwuanyi, Afr. J. of Agr R, 7 (48), 6401-6407 (2012)

12. T. Paskalis, B.B. Koten, R.Wea, J.S. Oemat, B. Ndoen, An. Sc. J, 16 (2), 22-27 (2016)

13. K. Jan, A.M. Rather, M.V. Boswal, A.H. Ganie, I. J. Agr. and C. Sc, 7 (4), 178-184 (2014)

14. M. Muchtar, I.K. Astawa, The Effect of Liquid Extract Organic Fertilizer of Centrosema (Centrosema pubescens) Leaf Sheats on The Growth and Biomassa Production of Elephant Grass (Pennisetum purpureum). (Proceeding of International Seminar "Improving Tropical Animal Production for Food Secuity" Halu Oleo University, Kendari, Southeast Sulawesi, 2015)

15. I.W. Kariuki, S.W. Mwendia, F.N. Muyekho, S.I Ajanga, D.O. Omaiyo, Afr. C. Sc. J, 24, 157-165 (2016)

16. S.S. Mahdi, G.I. Hassan, S.A. Samoon, H.A. Rather, S.A. Dar, B. Zehra, J. Phyt, 2 (10), $42-54$ (2010)

17. Jigme, N. Jayamangkala, P. Sutigoolabud, J. Inthasan, S. Sakhonwasee, J. O. Sys, 10 (1), 9-14 (2015)

18. E. Hendarto, Suwarno, J. L. Phys Sc, 15 (2), 86 -91 (2013)

19. A.K. Borrel, J.E. Mullet, B.G. Jaeggli, E.J. Oosterom, G.L. Hammer, P.E. Klein, D.R. Jordan, J. Exp. B, 65 No. 21, 6251-6263 (2014)

20. P. Ramakrishnan, C. Babu, K. Iyanar, I. J. Env. Agr. R, 2 (6), 142 - 146 (2016)

21. Setiyowati, S. Haryanti, R.B. Hastuti, Bioma, 12 (2), 44-48 (2010)

22. D.M.H. Karti, J. An. H, Vol. 27 (2), 63-68 (2004)

23. T. Karyono, Maksudi, Yatno, J. An. Sc. I, 12 (1), 102 111 (2017)

24. S. Aisyah, J. Agr, 2 (1), 1-5 (2001)

25. S. Tudsri, S.T. Jorgensen, P. Riddach, A. Pookpakdi, Tro. G, 36, 248-252 (2002)

26. S. Wijitphan, P. Lorwilai., C. Arkaseang, Pakistan J. N, 8 (8), 1244-1250 (2009)

27. E. Hendarto, Environmental Dimensions of Spatial Planning for People's Dairy Cattle in Banyumas District, Central Java Province, Dissertation (Graduate Program of Diponegoro University, Semarang, 2011)

28. L. Abdullah, D.D.S. Budhie, A.D. Lubis, Pastura, 1 (1), 5-8 (2011)
29. D. Soro, K. Ayolie, F.G.B. Zro, F.Y. Yeboua, H.K. Kouadio, S. Bakayoko, P.T. Angui, J.Y. Kauadio, J. of Exp. Bio. Agr. Sc, 3 (6), 556-565 (2015)

30. E.M. Nyambati, F.N. Muyekho, E. Onginjo, C.M. Lusweti, Production, Afr. J. P. Sc, 4(12), 496-502 (2010)

31. N.F. Rizqiani, E. Ambarwati, N. W. Yuwono, J. S. Env. Sc, 7 (1), 43-53 (2007)

32. Z.A. Huang, D.A. Jiang, Y, Yang, Y.W. Sun, S.H. Jin, Photosynthetica, 42 (3), 357-364 (2004)

33. A. Rahmi, Jumiati, Agritrop, 26 (3), 105-109 (2007)

34. D.H. Min, S.D. Timothy, W.J. Everman, A.J. Chomas, J.J. Kells, R.H. Leep, Weed Tech, 26, 399-404 (2012)

35. I.S. Madauna, J. Agr, 16 (1), 24-32 (2009)

36. A.A.C. Novo, R.F. Daher, G.A. Gravina, E.S. Costa, J. Ogliari, K.C. Araujo, B.R.S. Menezes, N.J. Pontiano, E.S. Oliveira, V.B. Silva, Afr. J. Biotech, 15 (43), 24112423 (2016) 